\title{
Left Dislocation in North-Eastern Neo-Aramaic dialects
}

\author{
Geoffrey Khan \\ Department of Asian and Middle Eastern Studies, University of Cambridge, United Kingdom \\ Email: gk101@cam.ac.uk
}

\begin{abstract}
The North-Eastern Neo-Aramaic (NENA) dialects, which are the focus of this paper, were spoken across a wide area encompassing northern Iraq, north-west Iran, south-eastern Turkey, Armenia and Georgia. In these spoken dialects a distinction should be made between two major types of Left Dislocation (LD) structures. In one type the initial item is prosodically and grammatically integrated with what follows. The initial item is prosodically integrated in that it is not separated from what follows by an intonation group boundary. The initial item is resumed in the clause by a pronominal affix, as opposed to an independent pronoun or a full nominal. Such initial items have all the semantic and functional properties of normal grammatical subjects. These are referred to as LD1 structures. A distinct type of construction is where the initial item is less integrated prosodically and/or structurally with what follows. This is referred to as an LD2 structure. This includes cases where the initial item is separated from what follows by an intonation group boundary. Another strategy for disjoining the initial item from the rest of the clause is the resumption of the initial item by an independent pronoun. Moreover, an additional structure in which the initial element is less integrated into the clause than LD1 constructions is where the resumptive element is a full nominal rather than a pronoun. An initial item in a LD2 structure is restricted to nominals that are topical, i.e. they function as the informational pivot or starting point of the following clause and typically their referent is identifiable from the context. The initial item of an LD1 structure, however, can have a variety of other types of status, including narrow focus. In this respect they correspond functionally to clause-initial subjects. When a clause-initial item has topical status, whether it be subject, an LD1 item or an LD2 item, the basic function of the construction is to express the onset of a discourse section and, if it occurs within the body of the discourse, a disjunction of some kind from what precedes. This includes not only topic shift, but also other types of discourse shifts, such as foreground to background or change in the level of description. In some cases, an LD1 construction is more normal than a construction with the grammatical subject in initial position, and indeed in some cases it is obligatory. This has given rise to diachronic change whereby the original grammatical subject of the construction has been re-analysed as having a different syntactic status.
\end{abstract}

Keywords: Left Dislocation, Information Structure, Neo-Aramaic, Discourse Pragmatics 


\section{Introduction}

The Neo-Aramaic dialects are normally divided into four main groups. These include (1) the western group spoken in Ma lula and various other villages in the region of Damascus, (2) the Turoyo group, spoken in Țūr 'Abdīn in south-eastern Turkey and in the village of Mlahsō in southern Turkey West of the Tigris river, (3) North-Eastern Neo-Aramaic (NENA), spoken east of the Tigris river, (4) neo-Mandaic, spoken in the cities of Ahwaz and Khorramshahr in southwestern Iran.

The North-Eastern Neo-Aramaic (NENA) dialects, which will be the focus of this paper, were spoken across a wide area encompassing northern Iraq, north-west Iran, south-eastern Turkey, Armenia and Georgia (Khan 2007). They include dialects spoken by both Jews and Christians. The Jewish dialects in all cases differ from the Christian dialects, even where the Jews and Christians lived in the same town or region (Hopkins 1993: 65).

\section{Structure of Left Dislocation Constructions}

A distinction should be made between two major types of Left Dislocation (LD) structures. In one type the initial item is prosodically and grammatically integrated with what follows, e.g.

$$
\begin{aligned}
& \text { 'o-náša }{ }^{+} \text {šúl-u } \quad u^{-}{ }^{+} \text {bàzar=ilal } \\
& \text { that-man job-his in-market=COP.3MS } \\
& \text { "The job of that man is in the market" (C. Urmi: Khan 2016b) }
\end{aligned}
$$

The initial item is prosodically integrated in that it is not separated from what follows by an intonation group boundary. The initial item is followed by a clause that contains a subject and predicate, so it has the structure of LD. The initial item is resumed in the clause by a pronominal affix, as opposed to an independent pronoun or a full nominal. As we shall see, such initial items have all the semantic and functional properties of normal grammatical subjects. These will be referred to in what follows as LD1 structures. Such LD1 constructions share with grammatical subjects the structural feature of resumption by a pronominal affix -in the case of subjects this is the subject marker pronominal affix of the verb. The initial item of analagous LD1 type constructions in Modern Hebrew and other languages are termed 'broad subjects' by Doron and Heycock (1999; 2003), Alexopolou, Doron and Heycock (2004), who regard the occurrence of the second subject as the result of the recursion of the subject-predicate relation.

A distinct type of construction is where the initial item is less integrated prosodically and/or structurally with what follows. This includes cases where the initial item is separated from what follows by an intonation group boundary, e.g.

$$
\begin{array}{llll}
\text { tàwral } & \text { primá-le } & \text { ðá 'ðð-e } & \text { diyel } \\
\text { ox } & \text { cutPERF-ERG.3MS } & \text { one hand-his his } \\
\text { "The ox-he cut off one of its feet" (A22:3) (Barwar: Khan 2008b) }
\end{array}
$$

Another strategy for disjoining the initial item from the rest of the clause is the resumption of the initial item by an independent pronoun, e.g. 
$\begin{array}{lcc}\text { (3) jawátta } & \text { 'áyya } & \text { t-pràzle-lal } \\ \text { chopper } & \text { PRON.3FS } & \text { GEN-iron-COP.3FS } \\ \text { "The chopper—it is (made) of iron" (B5:140) (Barwar: Khan 2008b) }\end{array}$

The two strategies may be combined, as in (4)

(4)

$\begin{array}{lllll}\text { baxt-ăkè, } & \text { 'ó } & \text { zilla } & \text { l-belál } & \text { batànel } \\ \text { wife-the } & \text { she } & \text { goPERF-ERG.3FS } & \text { to-home } & \text { by.self }\end{array}$

"The wife-she went home by herself" (L 257) (J. Arbel: Khan 1999)

Another structure in which the initial element is less integrated into the clause than LD1 constructions is where the resumptive element is a full nominal rather than a pronoun, e.g.

$$
\begin{aligned}
& \text { málla píš-la quṣárta ta-màllal } \\
& \text { mullah becomePERF-ERG.3FS pot to-mullah } \\
& \text { "The mullah—-the cooking pot became the mullah’s" (A5:10) (Barwar: Khan 2008) }
\end{aligned}
$$

A further type of lack of integration is constituted by cases where the initial item is left without any explicit resumption in the clause, e.g. ${ }^{1}$

$$
\begin{array}{llll}
\text { mexólta } & y \text {-áwa } & \text { mbúšle } & \text { qawúrma-w ràzzal } \\
\text { food } & \text { HAB-be.3PL } & \text { cook.PART.PL } & \text { qawurma-and rice }
\end{array}
$$

"As for the food, they would have cooked qawurma and rice" (B5:15) (Barwar: Khan 2008)

Occasionally a resumptive independent pronoun itself stands extraposed from the clause. This is attested only where there is an intonation group boundary before the independent pronoun, e.g.

$$
\begin{aligned}
& \text { xá-naša l-xóð-e } \\
& \text { litte } \\
& \text { one-man by-self.3MS } \\
& \text { NEG.COP-DAT.3MS } \\
& \text { la-bába } \\
& \text { la-yźmma la-'àp-xa, 'áw } \quad y \text {-amrìle } \\
& \text { not-mother no-any-one he HAB-say.3PL.-DAT.3MS } \\
& \text { litte } \\
& \text { nášel } \\
& \text { NEG.COP-DAT.3MS people }
\end{aligned}
$$

"A man by himself, who does not have a father, a mother or anybody — he - they say concerning him that he has no relatives" (A17:17) (Barwar: Khan 2008)

\section{Initial Item}

An initial item in a LD2 structure is restricted to nominals that are topical, i.e. they function as the informational pivot or starting point of the following clause and typically their referent is identifiable from the context:

\footnotetext{
${ }^{1}$ Cf. Andrason (2016b).
} 
(8)

$\begin{array}{llll}\text { tàwral } & \text { primá-le } & \text { ðá 'ðð-e } & \text { diye } \\ \text { ox } & \text { cutPERF-ERG.3MS } & \text { one hand-his his } \\ \text { "The ox-he cut off one of its feet" (A22:3) (Barwar: Khan 2008b) }\end{array}$

(9)
jawátta
'áyya
t-pràzle-la
chopper
PRON.3FS GEN-iron-COP.3FS
"The chopper-it is (made) of iron" (B5:140) (Barwar: Khan 2008b)

In many cases a clause-initial grammatical subject and an initial item in a LD1 structure have such a topical status:

LD1 item

$$
\begin{aligned}
& \text { 'o-náša }{ }^{+} \text {šúl-u } \quad j^{-{ }^{+} b a ̀ z a r=i l a l} \\
& \text { that-man job-his in-market=COP.3MS } \\
& \text { "The job of that man is in the market" (C. Urmi: Khan 2016b) }
\end{aligned}
$$

Subject
(11)

$$
\begin{array}{ll}
\text { 'o-náša } & \text { bət-'àtəl } \\
\text { that-man } & \text { FUT-come.3MS }
\end{array}
$$
"That man will come" (C. Urmi: Khan 2016b)

A clause-initial subject, however, can have a variety of other types of status. An initial item in a LD1 structure corresponds to a clause-initial grammatical subject with regard to its range of semantic and functional properties. In this respect LD1 items are different from LD2 since the latter are restricted to topical status. Properties that distinguish LD1 items and grammatical subjects from LD2 items include the possibility of their being a non-referential or downward entailing item, e.g.

LD1 item

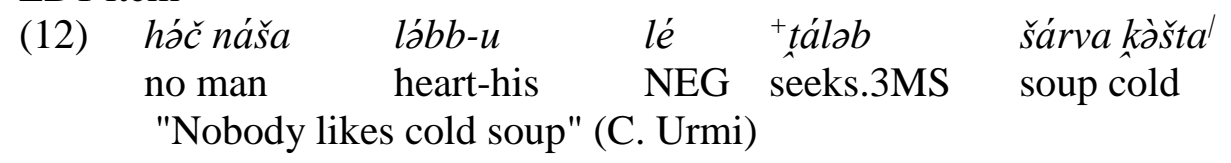

Subject
(13) háč náša

\begin{tabular}{|c|c|c|c|c|}
\hline $\begin{array}{l}\text { (14) nášə } \\
\text { people }\end{array}$ & $\begin{array}{l}{ }^{+} \text {basúr } \\
\text { few }\end{array}$ & $\begin{array}{l}\text { labb-é } \\
\text { heart-their }\end{array}$ & $\begin{array}{l}c i^{-}{ }^{+} t a ́ l a b \\
\text { HAB- seek.3MS }\end{array}$ & šárva kàšta \\
\hline
\end{tabular}
lé mag்g̀̀b-lal
no man NEG like.3MS-OBJ.3MS
"Nobody likes him" (C. Urmi)

LD1 item

Subject
(15) náša
${ }^{+}$basúra
ci-mag் gabbilal
people few
HAB-like.3PL-OBJ.3MS
"Few people like him" (C. Urmi) 
A LD1 item, like a grammatical subject, may be in narrow information focus, which is signalled prosodically by placing on it the nuclear stress of the intonation group, e.g.

LD1 item

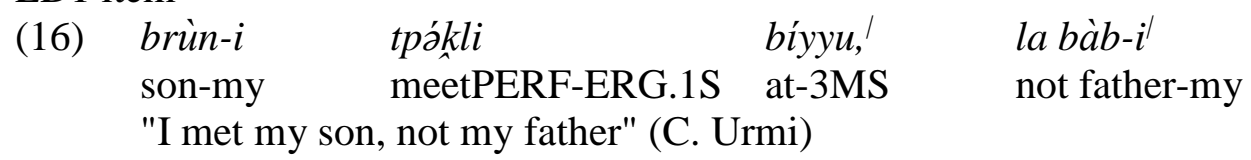

Subject

\begin{tabular}{|c|c|c|}
\hline $\begin{array}{l}\text { brùn-i } \\
\text { son-my }\end{array}$ & $\begin{array}{l}\text { bat-'áto, I } \\
\text { FUT-come.3MS }\end{array}$ & $\begin{array}{l}\text { la bàb-í } \\
\text { not father-my }\end{array}$ \\
\hline
\end{tabular}

In an LD2 construction narrow focus can only be expressed on a resumptive independent pronoun, as in (15) and (16):

(18) babá w-dă'á 'òni golí-wal

father and-mother they do.3PL-PST

"The father and mother- they (and nobody else) used to do it" (L:196) (J. Arbel: Khan 1999)
'o-t-pàlax $\quad$ 'àw $\quad$ t-áxol
he-REL-work.3MS he FUT-eat

"Whoever works—-he (and not anybody else) will eat" (A21:13) (Barwar: Khan 2008)

Both a LD1 item and a normal subject may be interrogative constituents, e.g. LD1 item

$\begin{array}{lll}\text { máni lább-u } & c{ }^{+}{ }^{+} \text {talıb } & \text { xabùyšə? } \\ \text { who heart-his } & \text { HAB-seek.3MS } & \text { apples } \\ \text { "Who wants apples?" (C. Urmi) } & \end{array}$

Subject

(21) máni ci-mag்gáb-la?

who HAB-like.3MS-OBJ.3FS

"Who likes her?" (C. Urmi)

Unlike the properties just described, which are restricted to clause-initial subjects and LD1 items, topicality is a property that is shared by clause-initial subjects, LD1 items and LD2 items. The topic of the clause is the starting point or pivot for the predication of the clause. It is typically some item whose referent is recoverable from the context. This may be due to its prior mention in the preceding discourse. ${ }^{2}$ Such linkage to the prior discourse is often signalled by an anaphoric demonstrative pronoun on the topical item, e.g.
'ó-'eða
y-amráx-le
šèral
that-festival
HAB-say.1PL-DAT.3MS festival
"That festival—we call it a šera (saint’s festival)" (B6:22) (Barwar: Khan 2008)

\footnotetext{
${ }^{2}$ Cf. Westbury (2016b).
} 
In some cases the initial topical item has not been explicitly mentioned in the preceding context, but is inferable from it in some way. In some cases the item is connected to what precedes in a set relationship. In (23), for example, the two extraposed nominals are items of a set of villages, which has been mentioned in what precedes:

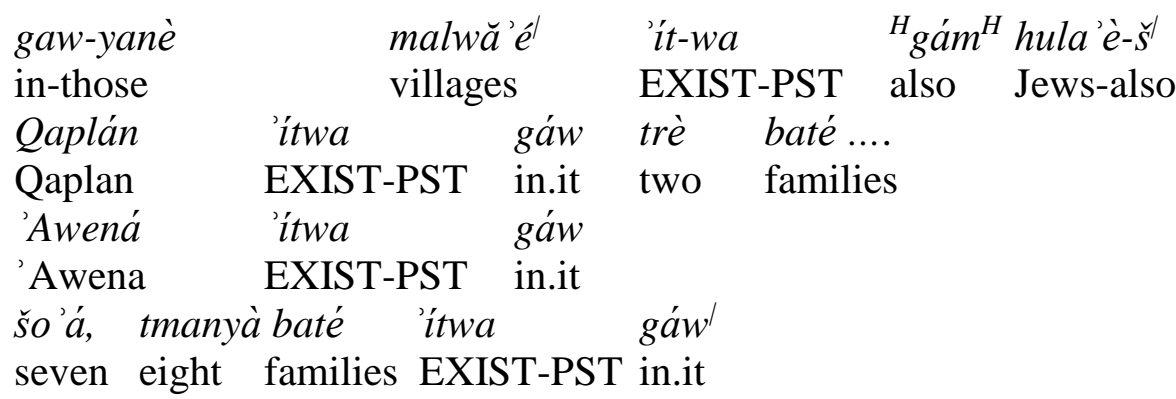

"In those towns there were also Jews. In Qaplan there were two families. ... In Awena there were seven or eight families" (B:31) (J. Arbel: Khan 1999)

A clause-initial topic may occur at the onset of a discourse without any preceding context. In such cases it may be identifiable due to its being a proper name with a referent that is assumed to be identifiable by the hearer, e.g.

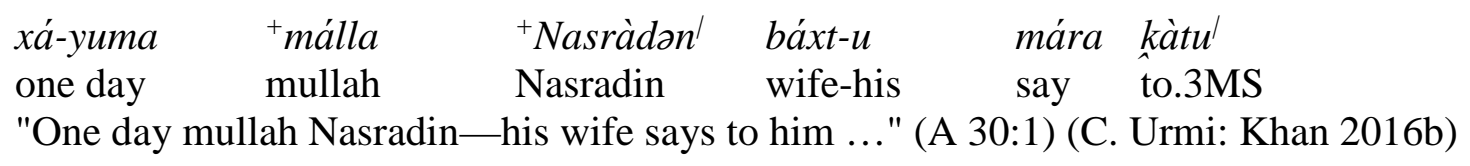

In (25) the initial topic in a clause in the onset of the discourse is referentially indefinite and so appears prima facie to be an unsuitable onset of a clause. It is, however, predictable from the general schema of narratives, which are typically about a specific man or boy. It can be said, therefore, to be inferable from the tradition schema of narratives.

$$
\begin{array}{llll}
\text { xá yàla báb-u } & \text { myàtalı. } \quad \text { xá } & \text { yámma } & \text { sòta váyulal } \\
\text { a boy father-his } & \text { die.COP.3MS one mother } & \text { old be.3MS.COP.3MS } \\
\text { "A boy-his father dies. He has an old mother" (A 34:1) } & \text { (C. Urmi: Khan 2016b) }
\end{array}
$$

The initial topic may refer to a generic class rather than a specific referent. The referent of the class is assumed to be recoverable from the knowledge of the hearer (26) or from the descriptive content of the nominal, as is the case in the nominalized relative construction in (27):

$$
\begin{array}{llll}
\text { bìral } & \text { xaprí-la } & b \text {-’’ða } & \text { xpàral } \\
\text { well } & \text { dig.3PL-OBJ.3FS } & \text { by-hand } & \text { dig.INF }
\end{array}
$$

"A well—they dig it by hand" (K:88) (Qaraqosh: Khan 2002)

$$
\begin{array}{llll}
g e b-a ̀ n & \text { o-t-kéwa } & x a \text { čày } & k m a ́ x-w a-l e \\
\text { with-1PL } & \text { he-REL-come.3MS-PST } & \text { one tea } & \text { bring.1PL-PST-DAT.3MS } \\
\text { "In our place, whoever came-we brought him a tea" (L 229) (J. Arbel: Khan 1999) }
\end{array}
$$


In dialogue, the referent of the initial topical item may be recoverable from the speech situation. This may be a 3rd person referent, as in (28), or one of the conversation participants (1st or 2nd person) (29-30): ${ }^{3}$

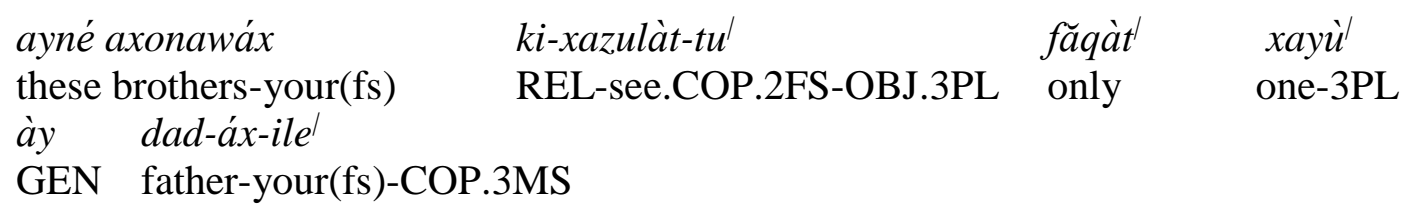

"These brothers of yours that you see, only one of them is from your father" (64) (J. Urmi: Khan 2008a)

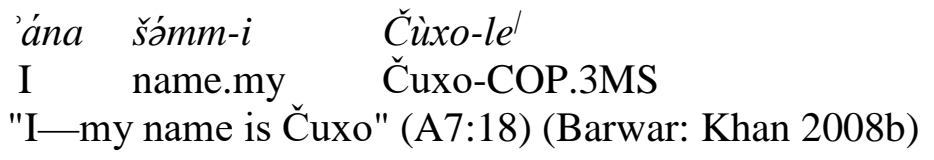

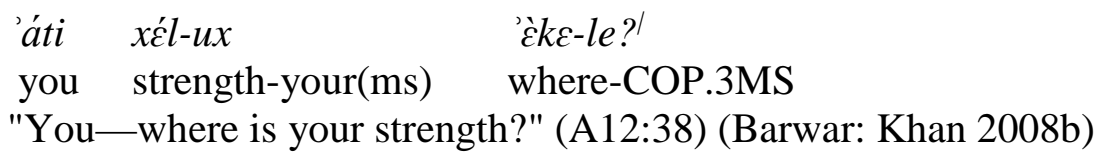

\section{Motivations for $L D$}

When a clause initial item has topical status, whether it be subject, an LD1 item or an LD2 item, the basic function of the construction is to express the onset of a discourse section and, if it occurs within the body of the discourse, a disjunction of some kind from what precedes. Examples where it occurs at the onset of a discourse or turn in dialogue are (24, 25, 28-30).

Within a discourse, a topical item may be placed in initial position to mark the onset of a section that shifts attention to a different topic. In such cases the different topic is often presented in parallel or contrastive opposition:
(31) xíllux táma mubsàmlux. I 'ána qəom-țarðili atePERF-ERG.2MS there enjoyPERF-ERG.2MS I PST-drive.3PL-OBJ.1S "You ate there and enjoyed yourself. I-they drove me out" (A2:11) (Barwar: Khan 2008b)

In narrative, the construction is used at the onset of a section that supplies some kind of elaboration on what precedes rather than carrying the narrative forward. The extrapositional clause in (32) provides an evaluative comment on what precedes rather than an event that is presented as sequential to what precedes.

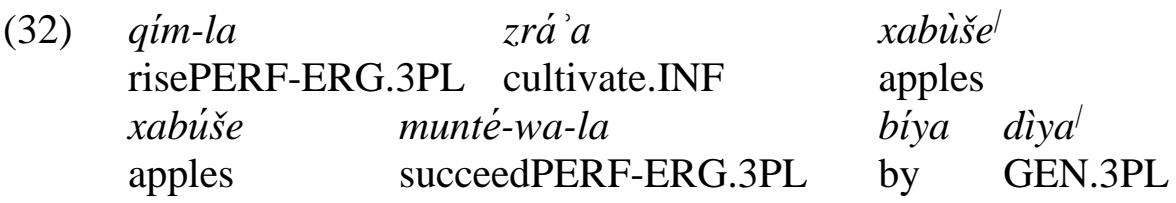

"They began to cultivate apples. Apples-they were successful with them" (B5:75) (Barwar: Khan 2008b)

\footnotetext{
${ }^{3}$ Cf. Westbury (2016a) section 3.1; and Westbury (2016b) section 3.
} 
In some cases the construction marks a shift from the foreground of the discourse to an elaborative background section, e.g. ${ }^{4}$

$$
\begin{aligned}
& \text { 'á címantí-va-la }{ }^{+}{ }^{+} a{ }^{-}{ }^{+} \text {ojàxtal } \\
& \text { this cauldron HAB-put.3PL-PST-OBJ.3FS on heart } \\
& \text { +ojáxta b-šónna kàmaya, kièsa ci-mattíva }{ }^{+} \text {'állol } \\
& \text { hearth in-years first wood HAB-place.3PL-PST on.3FS } \\
& \text { "They used to place this cauldron on the hearth. The hearth - in the early years, ... they }
\end{aligned}
$$

The passage in (33) is from a text concerning the production of molasses. The LD construction introduces a background section that describes the fuel of the hearth.

\begin{tabular}{|c|c|c|c|}
\hline & & $\begin{array}{l}\text { didàn,! } \\
\text { GEN.1PL, }\end{array}$ & \\
\hline & $\begin{array}{l}\text { hula'èl } \\
\text { Jews }\end{array}$ & $\begin{array}{l}\text { 'iyyá } \\
\text { this }\end{array}$ & $\begin{array}{l}\text { hašt- } u \\
\text { work-their }\end{array}$ \\
\hline
\end{tabular}

LD is used also where there is not necessarily a change in topic referent but there is, nevertheless, a discontinuity on some other level of discourse. In (34), for example, the LD construction coincides with a change of level of description, from a specific description to a general summarizing statement: ${ }^{5}$

"The Jews of our community, of Arbel, used to sew many quilts. ... The Jews- - this was their work" (L:18-20) (J. Arbel: Khan 1999)

In (35) the main topical referent of the narrative is an LD item both at the beginning of the story and also at the front of the clause that marks the shift from the introductory background of the story to the onset of the main narrative: ${ }^{6}$

$$
\begin{array}{lll}
\text { xá yàlal } & \text { yámm-u } & \text { myàtz-la } \ldots \\
\text { one boy } & \text { mother-his } & \text { die.INF-COP.3FS } \\
\text { 'á yàlal } & \text { báb-u } & \text { márzla ... } \\
\text { this boy } & \text { father-his } & \text { say.INF-COP.3MS } \\
\text { "A boy-his mother dies. .. " "This boy—his father says ..." (A 36:1) (C. Urmi: Khan } \\
\text { 2016b) }
\end{array}
$$

In (36) the use of a topical independent pronoun at the front of the second clause in an LD structure disjoins the clause from what precedes in order to give the assertion of the proposition added prominence: ${ }^{7}$

$$
\begin{array}{llllll}
\text { 'ána } & \text { là } & \text { yătúna. } & \text { 'ána } & \text { didì-č } & \text { qatlli } \\
\text { I } & \text { NEG } & \text { sit.1MS } & \text { I } & \text { OBJ.1S.-also kill.3PL } \\
\text { "I shall not stay. They will kill also me" (C:9) (J. Sanandaj: Khan 2009) }
\end{array}
$$

\footnotetext{
${ }^{4}$ Cf. Westbury (2016b) section 4.4.1.

${ }^{5}$ Cf. Westbury (2016b) section 4.5.2.

${ }^{6}$ Cf. Westbury (2016b) section 4.4.1.

${ }^{7}$ Cf. Westbury (2016b) section 4.4.3.
} 
The referent of the initial topic item is the pivot that sets the frame for what follows, to which the information of the proposition is attached. LD constructions arise when the speaker makes an item that is not the immediate subject of the clause the pivot. This is the norm in some constructions in which the immediate subject of the clause is intrinsically unsuitable to be the topical pivot. In constructions containing experiencer arguments, the experiencer is sometimes not the immediate subject but rather the subject is the nominal expressing what is experienced. In such cases a nominal expressing the experiencer is regularly placed in initial position in a LD construction:

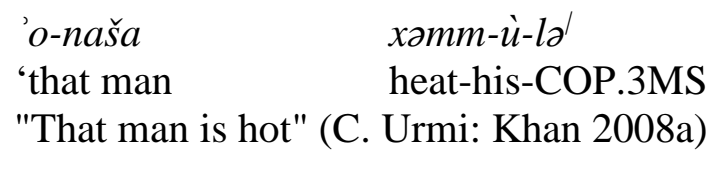

$\begin{array}{lll}\text { 'o náša } & \text { xóš-u } & \text { bitàya-lal } \\ \text { that man } & \text { goodness-his } & \text { come-COP.3MS } \\ \text { "That man is happy" (C. Urmi: Khan 2008a) }\end{array}$

$$
\begin{array}{ll}
\text { 'ána } & f ə k r-i-y e \\
\text { I } & \text { thought-my-COP.3MS } \\
\text { "I remember" (J. Sulemaniyya: Khan 2004, 393). }
\end{array}
$$

$$
\begin{array}{ll}
\text { našé pakk-ú } & \text { là-wele } \\
\text { people need-3PL } & \text { NEG-COP.PST.3MS }
\end{array}
$$

"People did not mind" (L:145) (J. Arbel: Khan 1999)

LD is also the norm when the immediate subject is impersonal. This applies to constructions such as (41-42), which are used to express the name of items, and (43) where ability is expressed by a verb with an impersonal subject:

\begin{tabular}{|c|c|c|}
\hline $\begin{array}{l}\text { 'ó-'eða } \\
\text { that-festival }\end{array}$ & $\begin{array}{l}y \text {-amráx-le } \\
\text { HAB-say.1PL-DAT.3MS }\end{array}$ & $\begin{array}{l}\text { šèral } \\
\text { festival }\end{array}$ \\
\hline That festiva & ll it a šera (saint's festival)" & B6:22) (Bal \\
\hline $\begin{array}{l}\text { 'axón-i } \\
\text { brother-my }\end{array}$ & $\begin{array}{l}\text { ké-le } \\
\text { come.3MS-DAT.3MS }\end{array}$ & $\begin{array}{l}\text { kălùl } \\
\text { write.3Ms }\end{array}$ \\
\hline
\end{tabular}

$$
\begin{array}{lll}
\text { ’áni } & \text { xațoryà } \theta a & y \text {-amrí-la } \\
\text { They } & \text { washing-boards } & \text { HAB-say.3PL-DAT.3PL }
\end{array}
$$

"They-they (impersonal) say to them "washing-boards" (= "They are called "washing- board.”) (B19:9) (Barwar: Khan 2008b)

"My brother-it comes to him to write (= My brother can write)" (J. Sulemaniyya: Khan 2004, 393)

In clauses denoting possession, the possessor is expressed by a dative pronominal suffix attached to an existential particle or verb 'to be'. If the possessor is a full nominal, this is obligatorily placed in a LD construction, e.g. 


$\begin{array}{ccc}\text { 'o- }^{+} k a t u ́ l a & \text { 'ótlo } & \text { š̀̀mmal } \\ \text { that-killer } & \text { EXIST-DAT.3MS } & \text { name }\end{array}$

"The killer has a name" (A 3:33) (C. Urmi: Khan 2016b)

$\begin{array}{lll}\text { 'át } & \text { lè-'avilux } & \text { brúnal } \\ \text { you } & \text { NEG-be.3MS-DAT.2MS } & \text { son } \\ \text { "You will not have a son" (A 3:5) } & \text { (C. Urmi: Khan 2016b) }\end{array}$

Although prima facie it may appear that the possessed item is the immediate subject of the existential particle or verb in such constructions, in some cases it does not have the grammatical agreement expected of a grammatical subject. In constructions containing the verb 'to be', a possessed item that is indefinite often does not have the expected subject agreement on the verb. In (46) the verb has 3ms agreement whereas the possessed item is feminine singular. In (47) the possessed item is plural, but the verb has 3fs agreement:

C. Urmi

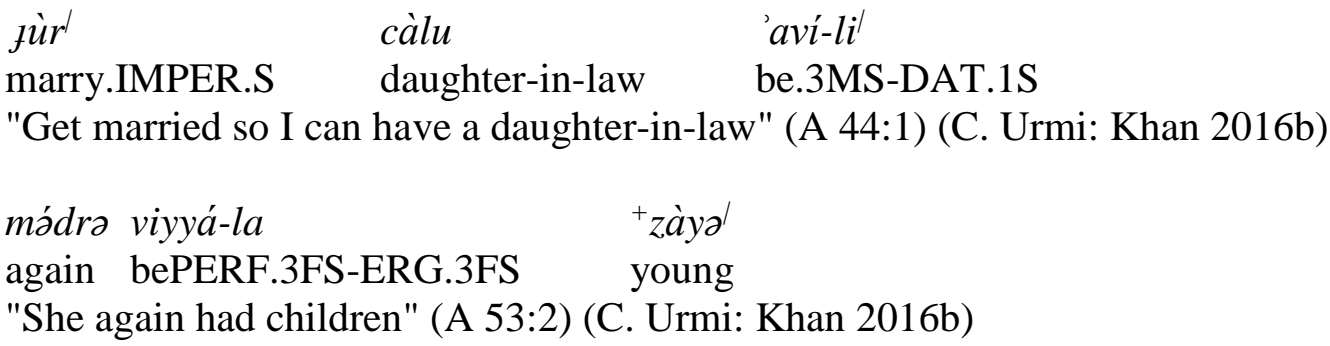

This can be interpreted as reflecting a syntactic reanalysis whereby the possessor has become the immediate subject of the construction. In constructions such as (44) and (45) above, therefore, the initial nominal can be considered to be the immediate grammatical subject rather than an LD item. The possessed item has come to be analysed as the grammatical object. It is relevant to note that there is differential object marking of grammatical objects in NENA dialects whereby object marking or object agreement is in principle restricted to definite objects.

In transitive past perfective clauses the suffixes agreeing with the subject nominal are ergative:

$$
\begin{array}{lcc}
\text { barux-ăwal-í } & \text { brat- } i & \text { garš- } a ̀-l u l \\
\text { friend-PL-my } & \text { daughter-my } & \text { pullPERF-3FS-ERG.3PL } \\
\text { "My friends pulled my daughter" (J. Sanandaj: Khan 2009) }
\end{array}
$$

Ergative suffixes are derived historically from dative suffixes consisting of the dative preposition $l$ - and a pronominal suffix. The historical origin of the construction is a passive construction in which the patient is the grammatical subject and the agent is expressed by an agentive adjunct by-phrase: 'My daughter was pulled by my friends'. A construction such as (48) would, therefore, have originally been LD, whereby the agent was not the immediate subject, but rather an LD item at the front of the clause resumed by an agentive dative phrase. In the contemporary NENA dialects, however, such passive constructions have developed into active ergative constructions in which the agent is syntactically the subject and the patient is syntactically the object. There are a number of arguments for this analysis (see Doron and Khan 2012; Khan 2016a), the main one being that the verb in principle does not agree with the patient 
argument if it is indefinite in conformity with the differential object marking conventions of NENA, e.g.

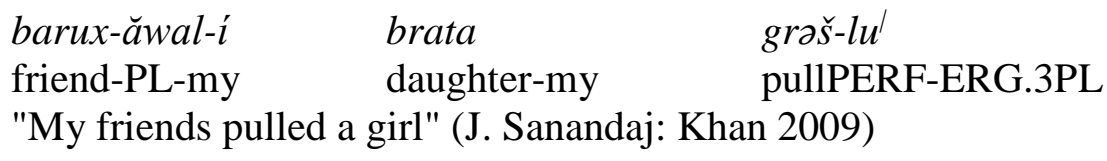

In ergative perfective constructions, therefore, the initial item expressing the agent should be interpreted as the immediate subject of the clause rather than an LD item.

The discourse boundary marking function of LD constructions with an initial topical constituent is performed also by subject-verb constructions with an initial topical subject constituent. This is seen clearly in the use of topical clause-initial independent subject pronouns, i.e. one that is not in narrow focus.

A topical independent subject pronoun is used when there is a change in subject, e.g.

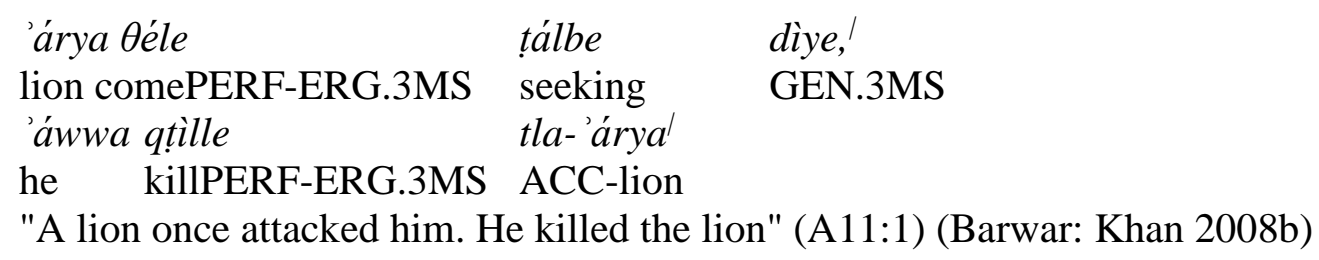

An independent pronoun is often used at the beginning of a turn in conversation, e.g.
már-e
'ána t-á日an
mànnax $\mid$
sayPERF-ERG.3MS I FUT-come.1MS with.2FS
"He said "I shall come with you" (A24:39) (Barwar: Khan 2008b)

On some occasions where an independent subject pronoun is used, there is no change in the subject referent. In such cases the use of the pronoun reflects a discontinuity on another level of the discourse. One such discontinuity is the lack of temporal sequence between the action of the clause and that of the adjacent discourse. The action of the clause may overlap temporally with it, e.g.

\begin{tabular}{|c|c|c|}
\hline $\begin{array}{l}\text { 'áza xázya } \\
\text { go.3FS see.3FS }\end{array}$ & $\begin{array}{l}\text { jùll-a, } \\
\text { clothes-her }\end{array}$ & $\begin{array}{l}\text { júll-a } \\
\text { clothes-her }\end{array}$ \\
\hline $\begin{array}{ll}\text { yya } & \text { šaqlàwale } \\
\mathrm{e} & \text { take.3FS-Ps }\end{array}$ & $\begin{array}{l}\text { ríxət } \\
\text { smell }\end{array}$ & $\begin{array}{l}\text { júlle } \\
\text { clothes }\end{array}$ \\
\hline
\end{tabular}

"She went to find her clothes, but her clothes were not there. She could smell the scent of the clothes" (A14:99-100) (Barwar: Khan 2008b)

Two clauses with different initial pronouns that are juxtaposed often express an opposition between two temporally overlapping events, e.g.

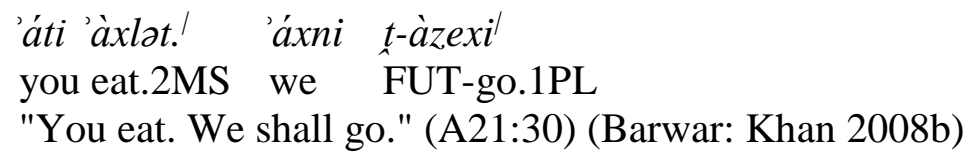


The discontinuity can sometimes be identified with the onset of a new section of discourse. This is seen in (54), in which the construction signals the onset of an event that is distinct from what is recounted in the preceding clauses. It marks the spatio-temporal shift in the event line in which the protagonist enters a different world.

\begin{tabular}{|c|c|c|c|}
\hline $\begin{array}{l}\text { 'u-xzéle } \\
\text { and-seePERF-ERG.3MS } \\
\text { 'áwwa pliṭ-le }\end{array}$ & $\begin{array}{l}\text { 'ina } \\
\text { behold } \\
\text { gu-ða-dúnye }\end{array}$ & $\begin{array}{l}\text { tằral } \\
\text { door }\end{array}$ & $\begin{array}{l}p \theta i x-a l-l e . \mid \\
\text { open-COP.3MS-OBJ.3MS } \\
\text { xètal }\end{array}$ \\
\hline exit-COP.3MS & in-one-world & & r \\
\hline
\end{tabular}

"He saw the door ... He opened it. He came out into another world" (A14:26) (Barwar: Khan 2008b)

In (55) from a narrative the pronoun is used in a clause that constitutes a disjunction from what precedes in that it offers an evaluative comment on the foregoing sequence of events:

\begin{tabular}{llll} 
'ay-zil & jáns lab-lè, & \multicolumn{1}{c}{ jans-ăké } & \\
he-goPERF.3MS & cloth takePERF-ERG.3MS cloth-ART & \\
lablé & mătúle & ga-xá dŭkaná & \\
takePERF-ERG.3MS put.3MS-OBJ.3MS & in-one shop & \\
zab-nè.। & 'áy-əč & xír & mangàl d-ól \\
sell.3MS-OBJ.3MS & he-TOP & becomePERF.3MS like GEN-3MS \\
"He went and took the cloth, he took the cloth away to put it in a shop and sell it. He \\
became like him (the neighbour)" (A:105) (J. Sanandaj: Khan 2009)
\end{tabular}

In some cases the main motivation to use an independent pronoun is to express the independence of the clause for the sake of giving it prominence. ${ }^{8}$ This appears to apply to the folowing:

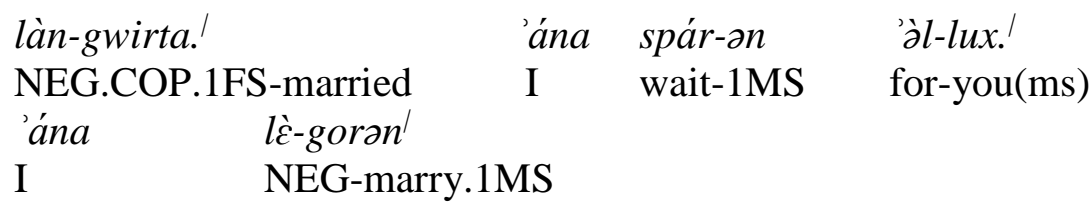

"I have not married. I am waiting for you. I shall not marry" (A25:83) (Barwar: Khan 2008b)

A clause initial subject constituent that is part of the same intonation group of the rest of the clause may also be in narrow focus, e.g.

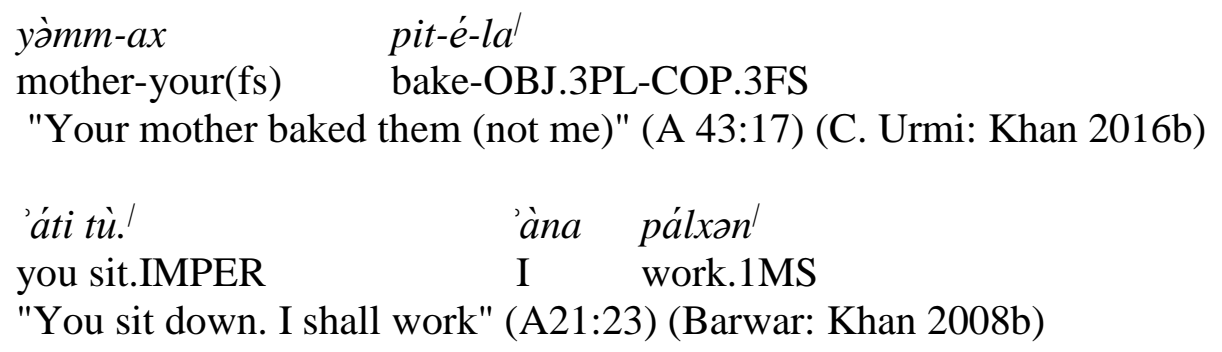

"You sit down. I shall work" (A21:23) (Barwar: Khan 2008b)

\footnotetext{
${ }^{8}$ Cf. Westbury (2016b) section 4.4.3.
} 
As has been remarked, this is possible also with LD1 constructions, e.g.

$\begin{array}{llcc}\text { brùn-i } & \text { tpákli } & \text { bíyyu, } & \text { la bàb-i } \\ \text { son-my } & \text { meetPERF-ERG.1S } & \text { at-3MS } & \text { not father-my } \\ \text { "I met my son, not my father" (C. Urmi: Khan 2016b) }\end{array}$

The marked position for the nuclear stress is at the front of the intonation group, so a constituent in narrow focus is placed at the front of the clause.

Both a clause initial subject and an initial LD1 item may be non-referential or a downward entailing constituent, e.g.

$\begin{array}{lll}\text { híč-kas } \quad l a & \text { hìe } \\ \text { noobody } & \text { NEG } & \text { comePERF.3MS } \\ \text { "Nobody came" (J. Sanandaj: Khan 2009) }\end{array}$
híč-kas
lăxă
la kəmrí-le
Mixa'èl
nobody
here NEG say.3PL-DAT.3MS
Mixa'el
"Nobody here is called Mixa' el" (J. Sanandaj: Khan 2009)

LD1 constructions of this nature are generally motivated by the intrinsic unsuitability of the grammatical subject to act as the initial constituent. In (61), for example, the grammatical subject is impersonal.

A clause initial subject constituent may be separated from the clause by an intonation group boundary, in which case it must be topical, as in LD2 constructions:
${ }^{+}$Nuxadnásar
màlcal ${ }^{+}$bəkráyz-la
${ }^{+}$rába náše
lipal
Nebechadnezzar
king call-COP.3MS
many men learned
"King Nebuchadnezzar summons many learned men" (A 3:42) (C. Urmi: Khan 2016b)

$$
\begin{aligned}
& \text { 'anàl băruxăwalé dòqnal } \\
& \text { I friends hold.1MS } \\
& \text { "I shall make friends" (D:3) (J. Sanandaj: Khan 2009) }
\end{aligned}
$$

All other things being equal, a construction in which a clause initial grammatical subject or LD item is separated from the rest of the clause by an intonation group boundary can be regarded as typically expressing a more prominent discourse boundary than one which consists of a single intonation group. According to Chafe (1994, 53, chapter 5) an intonation group coincides in cognitive terms with a single focus of consciousness and so an intonation group boundary constitutes a shift to another focus of consciousness. If we follow this view, we could say that a subject or LD that is in its own intonation group and separated from what follows by an intonation group boundary is cognitively more prominent than one that is part of a cognitive unit that includes also other elements. The endowment of an initial topical item with greater prominence could be expected to constitute a greater discourse boundary.

An LD2 construction like (64), in which the initial item is resumed by an independent subject pronoun, can be regarded as a recursion of the strategy of placing a topical constituent in initial 
position to mark a discourse boundary. It would, therefore, be expected to mark a more prominent discourse boundary than a corresponding, structurally lighter, construction without the independent pronoun, even when there is no prosodic break between the initial item and what follows.
jawátta
'áyya
t-pràzle-la
chopper
PRON.3FS GEN-iron-COP.3FS
"The chopper-it is (made) of iron" (B5:140) (Barwar: Khan 2008b)

The canonical, unmarked position of subject constituents in NENA dialects is before the verb. In some cases, however, a subject constituent is placed after the verb. The arrangement verbsubject should be considered to be the marked order. When this subject constituent has topical status and is linked anaphorically to the preceding discourse, the function of such marked verb-subject constructions is generally to express a close cohesion with what precedes (Khan 1999, 337-341; 2002, 427-434; 2008b, 858-860; 2008a, 327-328; 2009, 349-351; 2016b, para. 12.5.2.2.). When it is used in narrative, the close relationship with what precedes may be one of close temporal sequence and spatial continuity, e.g.

\begin{tabular}{|c|c|c|}
\hline mára & gáwṛa & ma-yxàləf. \\
\hline sayPERF.ERG.3FS & husband & NEG-matter.3MS \\
\hline b-șalyàna.' & șlígcla & bàxtal \\
\hline FUT-descend.1FS & descend-( & wife \\
\hline
\end{tabular}

"She said 'Husband, it's all right. I shall go down (to the town).' The woman went down" (A22:11) (C. Barwar: Khan 2008b)

Such postposition of a topical constituent is attested in LD1 constructions. It is found in possessive constructions such as (66), constructions with impersonal type subjects such as (67) or constructions such as (68) in which an experiencer argument is an LD item and a nominal expressing what is experienced is the grammatical subject:

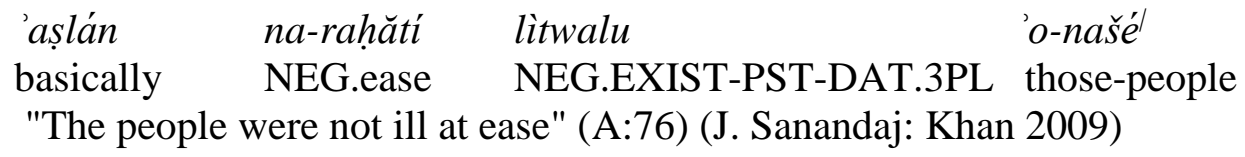

$\begin{array}{lllc}\text { čarči } & \text { kəmréxwa } & \text { báqu } & \text { 'onyexáe } \\ \text { peddler } & \text { HAB.say.1PL-PST } & \text { to.them } & \text { they }\end{array}$

"We called them "peddlers" (B:9) (J. Sanandaj: Khan 2009)

k̇̀̀dla lábbu $\quad \begin{gathered}\text { o-nášal } \\ \text { burnPERF-ERG.3MS heart-his } \\ \text { that-man }\end{gathered}$
"His heart burnt (with emotion)—-that man" (= that man was upset)

As we have seen, LD structures are the norm in possession constructions, in naming constructions with impersonal type subjects and constructions with experiencer arguments. There is evidence, moreover, of the reanalysis of the LD structure of possessive constructions as a subject-predicate construction. Ergative constructions are clearly subject predicate constructions, although historically LD. Such ergative constructions can have a topical subject postposed to express cohesion, e.g. 


$\begin{array}{ll}\text { 'inty-a-wa-le } & \text { 'axon-il } \\ \text { take-OBJ.3FS-PST-ERG.3MS } & \text { brother-my }\end{array}$

"My brother had taken it away" (R:105) (J. Sulemaniyya: Khan 2004)

LD constructions with experiencer arguments such as (68) do not exhibit any evidence of structural reanalysis, but the initial item behaves syntactically like a grammatical subject due to the inherent semantic properties of the arguments of the clause. Such inherent properties condition its behaviour like a grammatical subject on both the left and right periphery of the clause. Further examples of LD constructions with experiencer arguments that allow inversion on the right periphery are (70)-(72). When LD is conditioned by the discourse topicality of a particular argument rather than due to semantic properties of the arguments internal to the clause, then dislocation is not possible on the right periphery (73)—(75).

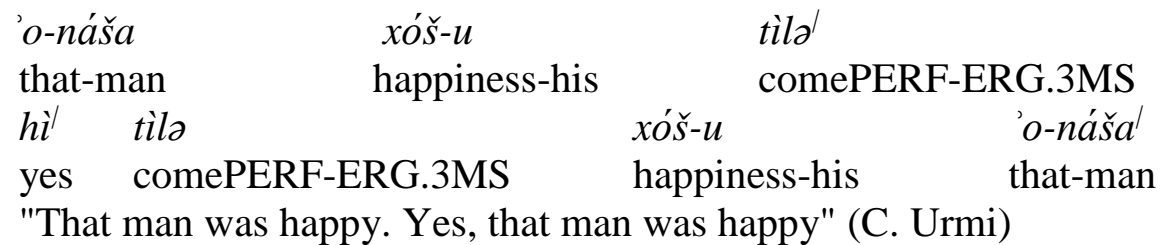

(71)

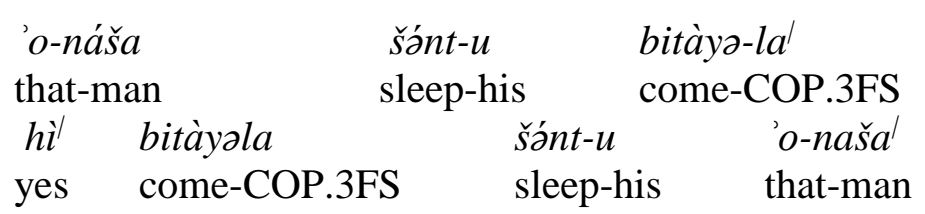

"That man is sleepy. Yes, that man is sleepy" (C. Urmi)

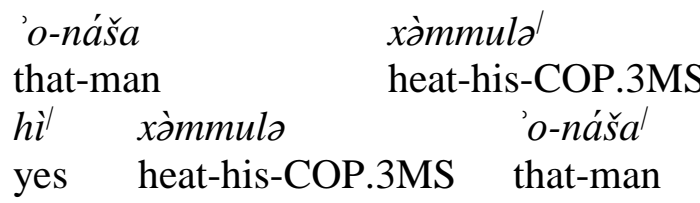

"That man is hot. Yes, that man is hot" (C. Urmi)

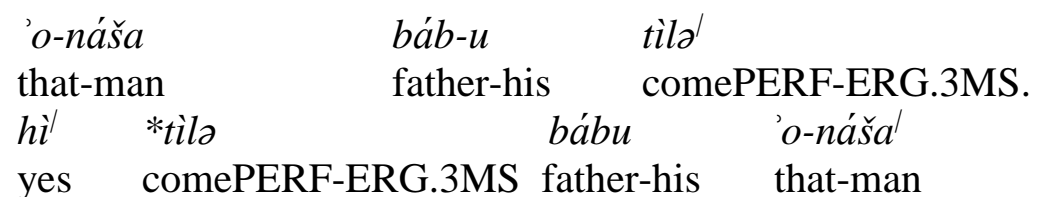

"That man —his father came. Yes, his father came—-that man" (C. Urmi)

(74)

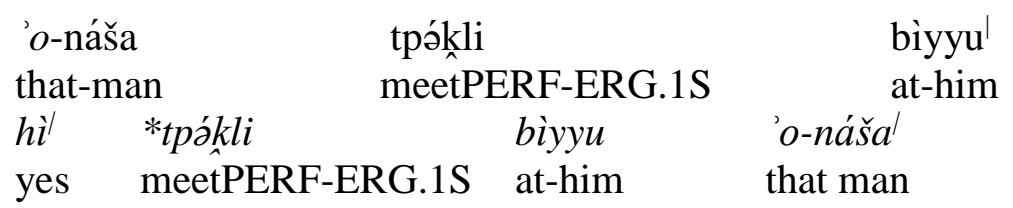

"That man-I met him. Yes, I met that man" (C. Urmi)

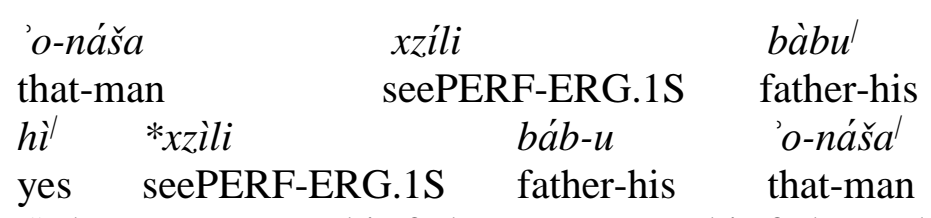

"That man—I saw his father. Yes, I saw his father-that man" 
These data can be interpreted as reflecting that recursion of the subject in dislocation constructions may take place in the unmarked clause-initial position of the subject (SV) but not in the post-verb marked position of the subject (VS) unless the immediate grammatical subject of the verb has inherent properties that make it behave like a non-subject grammatical relation.

A postposed grammatical subject may be separated from the rest of the clause by an intonation group boundary, e.g.

$$
\begin{aligned}
& { }^{+} \text {tájər mattùy-u-lə } \quad{ }^{+} \text {támmal } \\
& \text { merchant put-OBJ.3MS-COP.àlal } \\
& \text { "The bald man puts the merchant over there" (A 1:30-31) (C. Urmi: Khan 2016b) }
\end{aligned}
$$

Likewise constructions in which a dislocated experiencer argument on the right periphery that is separated from the rest of the clause by an intonation group boundary are attested, as in (77):
libb-éu
șipyà-wele
yá goràl
heart-his
pure-COP.PST-ERG.3MS this man
"His heart was pure, this man" (S:102) (J. Arbel: Khan 1999)

In NENA dialects a pronominal suffix on a verb may function as a case agreement suffix of a direct object.

$$
\begin{array}{ll}
\text { bratí } & \text { garàš-lal } \\
\text { daughter-my } & \text { pull.3MS-OBJ.3FS } \\
\text { "He pulls my daughter" (J. Sanandaj: Khan 2009) }
\end{array}
$$

A construction such as (78) has the appearance of an LD construction, in which the initial item would be extraposed and the object suffix would be resumed on the verb. The pronominal suffix should, however, be interpreted as an agreement suffix rather than a resumptive suffix. ${ }^{9}$ The initial item is the grammatical object and the suffix is a case agreement suffix. Such agreement typically occurs with definite objects, in accordance with the differential object marking conventions of NENA. It can be said that the object has accusative case, which is marked by the agreement suffix on the verb. This status of the nominal is shown by the fact that it is not restricted to initial position (79-80):

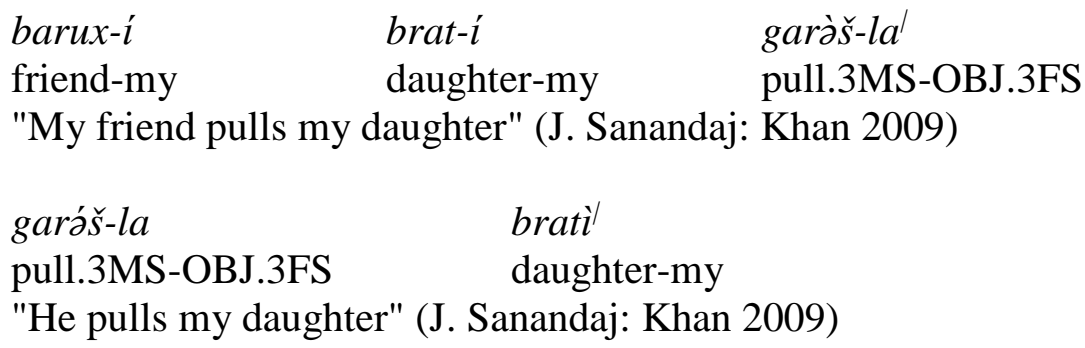

There are differences across the NENA dialect with regard to the canonical position of the object constituent in verbal clauses. In some dialects the canonical order is SOV and in other dialects it is SVO. In each group of dialects the object may be moved to the opposite side of the

\footnotetext{
${ }^{9} \mathrm{Cf}$. Andrason and Visser Ch. 7, this volume, where resumptive elements in Xhosa are indistinguishable from those exhibiting object agreement.
} 
verb in some cases in order to perform particular discourse pragmatic functions. In dialects in which the canonical unmarked order is $\mathrm{OV}$, the marked order is VO, whereas in dialects in which the unmarked order is VO, the marked order is OV. The marked order of the object relative to the verb performs similar functions across the dialects, although in one group of dialects the marked order is VO and the other it is OV. In clauses without an initial subject constituent, which are in the majority in natural discourse, a construction in which a topical object is put in the marked order is typically used to express close cohesion with what precedes. In (81), for example, from J. Sanandaj, which has an unmarked OV order, the marked order VO is used in the final clause to express cohesion in order to present the act of going up to the people and listening to what they say as aspects of the same overall event and not independent events:

$$
\begin{aligned}
& \text { gezál-wa ... xá-'̇da našé ke-ga-xá meydấn } \\
& \text { go.3MS-PST one-group people REL-in-one square } \\
& \text { smixèn xábra hăqèn,! mășílwa xabrùl } \\
& \text { standing-COP.3PL word speak.3PL listen.3MS-PST word-their }
\end{aligned}
$$

"He would go ... to a group of people who were standing in a square speaking and listen to what they said" (A:109) (J. Sanandaj: Khan 2009)

In (82) the construction with a postposed object is used in a clause that recapitulates the content of what precedes rather than advancing the discourse:

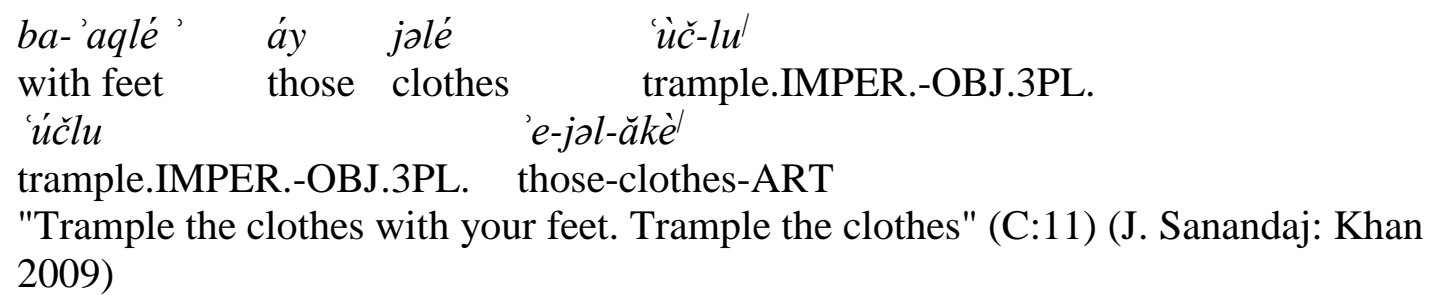

In a dialect in which the unmarked order is VO, such as C. Urmi, the marked order OV is used to express cohesion in the same way, when the object constituent is topical. In (83), for example, the OV clause presents an event as occurring in close spatio-temporal sequence to the preceding event, as an aspect of the same overall event:

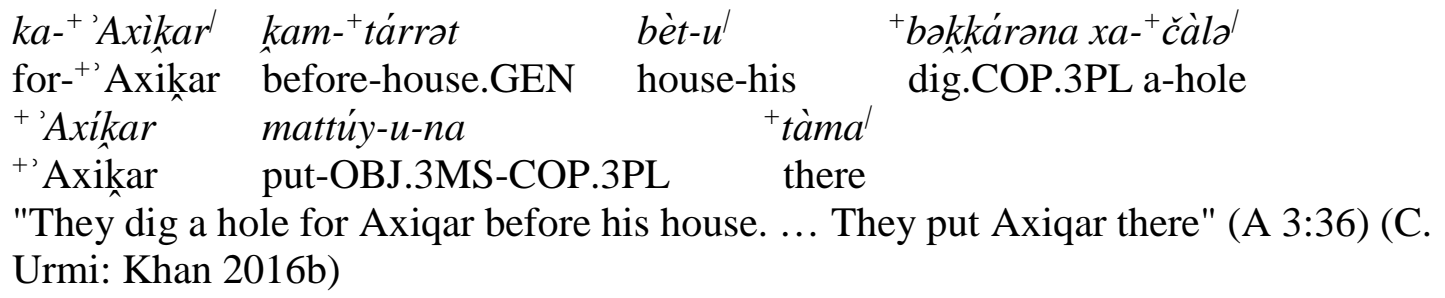

In (84) the cohesion may be one of overlap, in that the clause is a reiteration of the content of what precedes, e.g.

C. Urmi

$\begin{array}{lll}\text { (84) }{ }^{+} \text {Nuxadnásər màlca }{ }^{+} & { }^{+} \text {bokráyə-la } & { }^{+} \text {rába náše lipol } \\ & \text { call-COP.3MS } & \text { many people learned }\end{array}$




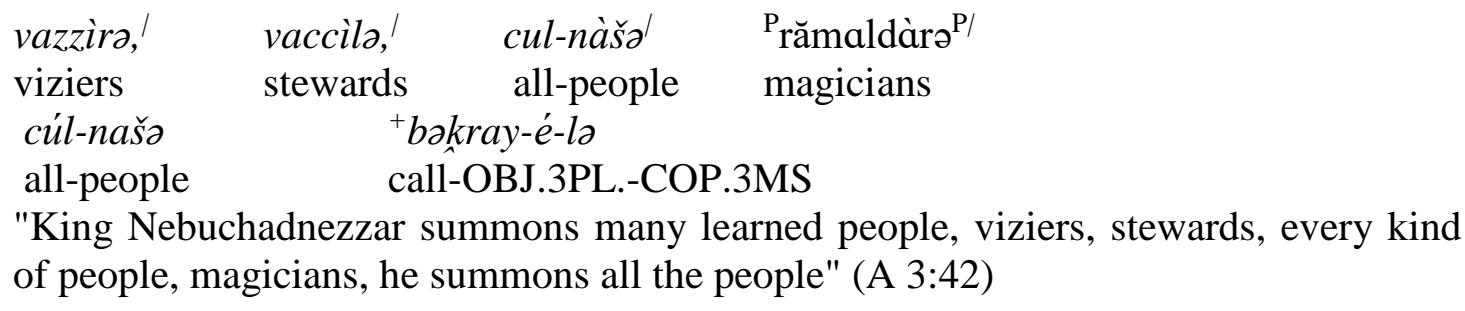

The point that needs to be emphasized here is that a construction with an object before the verb and a coreferential pronominal object suffix on the verb as in (78), although it resembles an LD1 structure on the surface, has a different function, since it does not mark a discourse boundary like LD1 constructions. So the grammatical relation of the fronted constituent has an impact on the discourse pragmatic function of the clause.

On the other hand, constructions such as (85) and (86) in which an initial topical constituent is disjoined from the clause by a prosodic break and/or an independent pronoun have a discourse boundary marking function and they can be considered to be LD2 constructions:

$$
\begin{array}{lcc}
\text { 'a-šṫ̀̇al har-tàma mpaltáxwalal } \\
\text { this-drink just-there produce.1PL-PST-OBJ.3FS } \\
\text { "We produced that drink there" (B5:11) (Barwar: Khan 2008b) }
\end{array}
$$

$$
\begin{array}{lcc}
\text { 'ó dàykul } & \text { +'ávun ci-payyíval } & \text { làxmal } \\
\text { that fine-3MS it } & \text { HAB-bake.3PL-OBJ.3MS } & \text { bread } \\
\text { "The fine one-they would bake it into bread" (B 17:9) } & \text { (C. Urmi: Khan 2016b) }
\end{array}
$$

In conclusion, the NENA dialects exhibit a variety of LD structures. These differ in the degree of integration of the LD item into the clause. In some constructions that are historically LD the initial constituent has now been reanalysed as the immediate grammatical subject and so the clause contains only one subject. This has taken place in ergative constructions and also in possessive constructions. In some constructions LD is the norm due to the fact that it is conditioned internally within the clause by the semantic properties of the arguments rather than by the external discourse. This applies to LD constructions with experiencer arguments or impersonal grammatical subjects. In other LD constructions, the LD is conditioned by the relationship of arguments to the external discourse.

The initial item in LD1 structures, which is linked prosodically to the following clause and bound to it referentially by a light pronominal affix, has the semantic and functional properties of grammatical subjects, in that it can be in narrow focus or it can be a non-referential or a downward entailing item. Such initial items, however, behave like grammatical subjects on the right periphery only if the LD is conditioned by the inherent properties of the arguments that are internal to the clause.

In LD2 constructions the initial item is prosodically separated from the following clause and/or is disjoined from the clause by an intervening independent pronoun. Unlike LD1 structures, the initial item of LD2 structures does not have the full range of semantic and functional properties of grammatical subjects. It is restricted to topical subjects. It follows from this that intonation group boundaries have a crucial effect on the function of the LD constructions. 
LD1 and LD2 topical constituents have a function analogous to that of topical grammatical subjects but different from that of clause initial topical objects, even when the object has pronominal agreement on the verb. Topicality of the initial item alone, therefore, does not determine the function of the construction, but rather the grammatical relation of the item is also a factor. It follows that LD1 and LD2 items should be considered types of subjects. LD1 items are more grammaticalized as subjects than LD2 items, which have greater pragmatic restrictions. It may be said LD2 items have the prototypical property of subjects, i.e. topicality, whereas the LD1 items, which are more advanced in their grammaticalization as subjects, allow, in addition to the prototypical property, also non-prototypical properties of subjects, such as narrow focus, which can be regarded as being rather a proto-typical property of predicates. The grammaticalization process is more advanced in clauses in which the LD is conditioned internally by the semantic properties of the arguments. The completion of the grammaticalization process is exhibited by historically LD constructions in which the original grammatical subject in the clause has become reanalysed as having a different grammatical relation and so now the construction has a single grammatical subject.

\section{References}

Alexopoulou, T., E. Doron, and C. Heycock. 2004. Broad subjects and clitic left dislocation. In D. Adger, C. de Cat, and G. Tsoulas (Eds.) Peripheries: Syntactic Edges and Their Effects. Dordrecht: Kluwer. pp. 329-358.

Chafe, W. L. 1994. Discourse, Consciousness, and Time: The Flow and Displacement of Conscious Experience in Speaking and Writing. Chicago: University of Chicago Press.

Doron, E., and C. Heycock. 1999. Filling and licensing multiple specifiers. In D. Adger, S. Pintzuk, B. Plunkett, and G. Tsoulas (Eds.) Specifiers: Minimalist Approaches, Oxford: Oxford University Press. pp. 69-89.

Doron, E., and C. Heycock. 2003. Categorical Subjects. Gengo Kenkyu 123. 95-135.

Doron, Edit, and Geoffrey Khan. 2012. The Typology of Morphological Ergativity in Neo Aramaic. Lingua 122. 225-40.

Khan, G. 1999. A Grammar of Neo-Aramaic: The Dialect of the Jews of Arbel. Boston, MA: Brill Academic Publishers.

Khan, G. 2002. The Neo-Aramaic Dialect of Qaraqosh. Studies in Semitic Languages and Linguistics 36. Boston, MA: Brill.

Khan, G. 2004. The Jewish Neo-Aramaic Dialect of Sulemaniyya and Halabja. Studies in Semitic Languages and Linguistics 44. Leiden: Brill.

Khan, G. 2007. The North Eastern Neo-Aramaic Dialects. Journal of Semitic Studies 52. 1-20.

Khan, G. 2008a. The Jewish Neo-Aramaic Dialect of Urmi. Gorgias Neo-Aramaic Studies. Piscataway: Gorgias. 
Khan, G. 2008b. The Neo-Aramaic Dialect of Barwar. Leiden: Brill.

Khan, G. 2009. The Jewish Neo-Aramaic Dialect of Sanandaj. Piscataway, NJ: Gorgias Press.

Westbury, J. 2016a. Left Dislocation: a typological overview. Stellenbosch Papers in Lingusitics Plus 50. 21-45.

Westbury, J. 2016b. A Functional Profile of Left Dislocation in Biblical Hebrew. Stellenbosch Papers in Lingusitics Plus 50. 65-90. 